\title{
Extracorporeal life support and systemic inflammation
}

\author{
Abdulrahman Al-Fares ${ }^{1,2,3}$, Tommaso Pettenuzzo ${ }^{1,3}$ and Lorenzo Del Sorbo ${ }^{3,4^{*}}$ (D) \\ From The 3rd International Symposium on Acute Pulmonary Injury Translational Research, under the auspices of the: 'IN- \\ SPIRES ${ }^{\circledR}$ \\ Amsterdam, the Netherlands. 4-5 December 2018
}

\footnotetext{
* Correspondence:

lorenzo.delsorbo@utoronto.ca

${ }^{4}$ Toronto General Hospital, 585

University Avenue, PMB 11-122,

Toronto, Ontario M5G 2 N2, Canada

Full list of author information is

available at the end of the article
}

\begin{abstract}
Extracorporeal life support (ECLS) encompasses a wide range of extracorporeal modalities that offer short- and intermediate-term mechanical support to the failing heart or lung. Apart from the daily use of cardiopulmonary bypass (CPB) in the operating room, there has been a resurgence of interest and utilization of venoarterial and veno-venous extracorporeal membrane oxygenation (VA- and W-ECMO, respectively) and extracorporeal carbon dioxide removal $\left(\mathrm{ECCO}_{2} \mathrm{R}\right)$ in recent years. This might be attributed to the advancement in technology, nonetheless the morbidity and mortality associated with the clinical application of this technology is still significant. The initiation of ECLS triggers a systemic inflammatory response, which involves the activation of the coagulation cascade, complement systems, endothelial cells, leukocytes, and platelets, thus potentially contributing to morbidity and mortality. This is due to the release of cytokines and other biomarkers of inflammation, which have been associated with multiorgan dysfunction. On the other hand, ECLS can be utilized as a therapy to halt the inflammatory response associated with critical illness and ICU therapeutic intervention, such as facilitating ultra-protective mechanical ventilation. In addition to addressing the impact on outcome of the relationship between inflammation and ECLS, two different but complementary pathophysiological perspectives will be developed in this review: ECLS as the cause of inflammation and ECLS as the treatment of inflammation. This framework may be useful in guiding the development of novel therapeutic strategies to improve the outcome of critical illness.
\end{abstract}

Keywords: Inflammation, Biomarkers, Cytokines, Extracorporeal life support, Extracorporeal membrane oxygenation, Extracorporeal carbon dioxide removal, Cardiopulmonary bypass

\section{Background}

Inflammation is a central facet in the complex pathophysiology of critical illness. Irrespective of cause, critical illness initiates the innate and adaptive immune systems, resulting in systemic inflammatory response syndrome (SIRS) [1-6]. Elevated levels of pro-inflammatory cytokines have been associated with mortality in trauma, complex surgical interventions, sepsis, adult respiratory distress syndrome (ARDS), and cardiogenic shock [7]. Additionally, anti-inflammatory response if unbalanced results in

(C) The Author(s). 2019 Open Access This article is distributed under the terms of the Creative Commons Attribution 4.0 International License (http://creativecommons.org/licenses/by/4.0/), which permits unrestricted use, distribution, and reproduction in any medium, provided you give appropriate credit to the original author(s) and the source, provide a link to the Creative Commons license, and indicate if changes were made. 
anergy and immunosuppression [8]. Furthermore, multiple organ failure has been postulated to be due to massive activation of inflammatory mediators by critical illness resulting in vascular endothelial damage, permeability edema, and impaired oxygen availability to mitochondria [9]. Following the inception of modern intensive care units (ICU), therapeutic interventions and life support strategies have led to significant reduction in inflammatory mediators and hence mortality [10-14].

Extracorporeal life support (ECLS) is a term than has been used interchangeably with extracorporeal membrane oxygenation (ECMO), but it encompasses all extracorporeal technologies, including cardiopulmonary bypass (CPB), ECMO in all its configurations, and extracorporeal carbon dioxide removal $\left(\mathrm{ECCO}_{2} \mathrm{R}\right)$. Since the success of $\mathrm{CPB}$ for short-term circulatory support in the 1950's, enthusiasm has grown to translate this technology to intermediate and long-term support for critically ill patients [15]. The first report of the use of veno-arterial extracorporeal membrane oxygenation (VA-ECMO) for respiratory failure was two decades later [16]. Although initial randomized clinical trials failed to demonstrate any clinical benefit of this technique [17, 18], with the advancement in technology and improvement in the safety profile, a resurgence of ECMO have been seen in the last decade with an exponential expansion in the number of ECMO centers worldwide. Moreover, improvement in outcomes has also been reported with survival of $57 \%$ to hospital discharge for patients with respiratory failure and $41 \%$ to hospital discharge for patients with cardiac failure [19].

Although lifesaving in many situations, complications of ECLS, whether mechanical, pump related, secondary to bleeding, or infection, are common and often contribute to morbidity and mortality $[15,19]$. One of the relevant complications of ECLS is the associated inflammatory response. A rapid rise in pro-inflammatory cytokines following initiation of ECLS [20-22] is thought to be associated with an innate immune response [23], which if severe may lead to end-organ dysfunction and death [24, 25].

It is challenging to discern the extent of the inflammatory response that is solely due to ECLS or due to critical illness, underlying disease or ICU therapeutic interventions including complex surgical procedures and mechanical ventilation (MV) [26-30]. Furthermore, while the potential mechanical and inflammatory injury caused by other means of life support such as MV is well recognized within the critical care community [31], the importance of the inflammation associated with the application of ECLS is less understood.

In addition to addressing the impact on outcome of the relationship between inflammation and ECLS, two different but complementary pathophysiological perspectives will be developed in this review: ECLS as the cause of inflammation and ECLS as the treatment of inflammation (Fig. 1). This framework may be useful in guiding the development of novel therapeutic strategies to improve the outcome of critical illness.

\section{ECLS as a cause of systemic inflammation}

Upon exposure of blood to the extracorporeal circuit during ECLS an inflammatory response might be triggered that mimics SIRS [32]. This is mediated by both humoral and cellular activation pathways, which are fundamentally interdependent but not fully understood during ECLS [33]. Most of the investigations on this specific issue have been developed with the CBP system, and hence a comprehensive evaluation is limited by the lack of rigorous studies on this issue conducted on ECMO and $\mathrm{ECCO}_{2} \mathrm{R}$. 


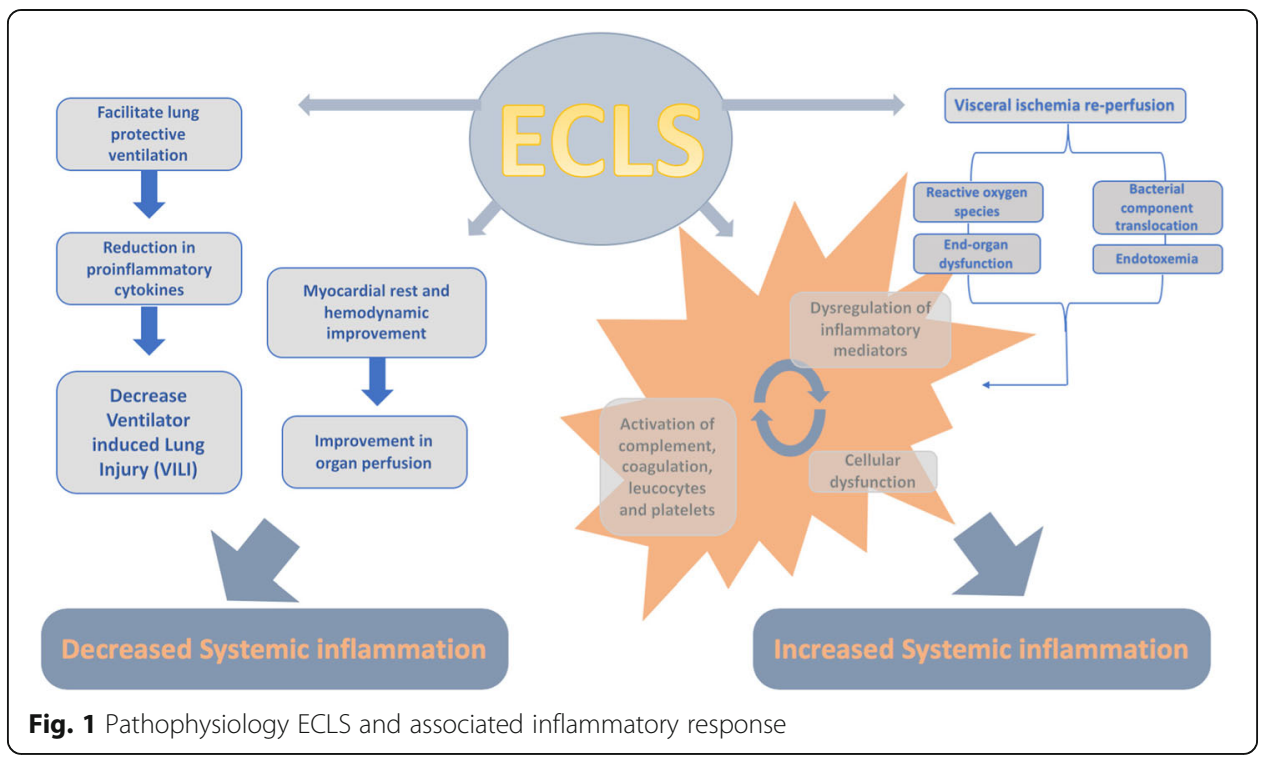

Additionally, a majority of the studies are conducted in neonates and pediatrics and used an older technology, with less advanced pumps, circuits, and biocompatible materials, pre-dating modern ECLS. Therefore, the findings can be only prudently extended to all the more modern ECLS configurations and uses.

\section{Contact system, coagulation cascade, and complement}

Following initiation of ECLS, the contact system becomes activated and subsequent byproducts of this activation promote coagulation and drive inflammation [33]. This activation process is rapid [34], resulting in neutrophil activation, release of nitric oxide and pro-inflammatory cytokines, as demonstrated during CPB [35, 36] and in neonatal ECMO [23]. The contact system activation triggers both intrinsic and extrinsic coagulation pathways, leading to clot formation and inflammation [33]. Notably, in simulated closed ECC, the expression of tissue factor (TF) by activated monocytes, or alternatively the TNF- $\alpha$ - and IL-6-induced release of soluble TF by endothelial cells, was evident without the need to be triggered by tissue injury and resulted in a 30-fold increase in thrombin formation [37, 38]. The complement system is also triggered upon initiation of ECLS [23, 39]. This mechanism is usually rapid with a peak in $1-2 \mathrm{~h}[23,40-42]$ but is short lived and limited to 1-2 days following initiation of ECLS [40, 43]. This activation is mediated by C5a, C3a, C3b, and terminal complement complex and causes an increase in leukocyte recruitment, vascular permeability, and endothelial dysfunction [40, 43, 44].

\section{Role of platelets}

Platelets are a major mediator of inflammation and not just hemostasis during ECLS [45]. Platelet activation has been extensively studied during СРB [46]. CPB causes structural and biochemical changes in platelets including differential expression of membrane receptors and formation of platelet conjugates due to shear forces created by circulatory pumps [47]. Less is known on the mechanisms of platelet activation 
during ECMO and $\mathrm{ECCO}_{2} \mathrm{R}$. In one of these investigations in neonates supported with VV-ECMO for respiratory failure, platelets were found to adhere to the fibrinogen absorbed by the circuit, resulting in a time-dependent platelet activation along with persistent and progressive platelet dysfunction leading to the release of pro-inflammatory cytokines and expression of TF $[48,49]$.

\section{Role of the endothelium and leukocytes}

Endothelial dysfunction in critical illness has been associated with poor outcomes [50] and plays also a major role in ECLS-induced inflammation. Alteration in endothelial cell gene expression occurs due to the effect of cytokines, complement, and reactive oxygen species, leading to pro-inflammatory mediators release and increased transmigration of leukocytes $[48,51]$. The resulting neutrophil infiltration has been described to lead to ECLS-associated lung injury and end-organ damage [23-25, 52, 53]. Activation of neutrophils has been found in an experimental simulated ECC to be instantaneous [54], peaking within the first few hours of ECMO initiation and declining thereafter [55].

\section{Bacterial translocation}

Other potential inflammatory mechanisms studied during ECLS are gut barrier dysfunction, bacterial translocation, and endotoxins release. During CPB and ECMO, endotoxins can be released in response to translocation of bacteria from ischemic gut mucosa into the blood stream [56, 57]. Lipopolysaccharide is released by Gram-negative bacteria and induces macrophages to release TNF- $\alpha$ and endothelial cells to release IL-6 [58]. Endotoxins stimulate circulating monocytes to produce cytokines, such as TNF- $\alpha$ [59] and blood-borne TF [60], thereby activating the coagulation cascade. Additionally, thrombin generation promotes inflammation, leading to a vicious circle.

\section{Human leukocyte antigen sensitization}

Another interesting mechanism by which ECLS may promote inflammation is by triggering human leukocyte antigen (HLA) sensitization in subjects bridged to transplant with extracorporeal means of life support. HLA sensitization has been reported in pediatric patients supported with a ventricular assist device and ECMO while awaiting heart transplant $[61,62]$. In addition, a recent report indicated that also patients bridged to lung transplant with ECMO might develop HLA sensitization [63]. However, the potential etiological mechanisms resulting into allosensitization during ECMO remain unclear and speculative.

\section{CBP-specific inflammatory response}

CPB involves unique features that further contribute to inflammation (Table 1). The clamping of the aorta during surgery inflicts an ischemia-reperfusion injury to both the heart and the lungs and results in a significant inflammatory reaction [64]. Moreover, the protamine administered at the end of $\mathrm{CPB}$ for heparin reversal results in protamine-heparin complexes that are known to exacerbate the inflammatory response via activation of the classical and lectin complement pathways [65]. Furthermore, 
Table 1 ECLS modalities

\begin{tabular}{|c|c|c|c|c|}
\hline & $\mathrm{CPB}$ & VA-ECMO & W-ECMO & $\mathrm{ECCO}_{2} \mathrm{R}$ \\
\hline Organ support & $\begin{array}{l}\text { Cardiac and } \\
\text { pulmonary }\end{array}$ & Cardiac and pulmonary & $\begin{array}{l}\text { Pulmonary: oxygenation } \\
\text { and ventilation }\end{array}$ & $\begin{array}{l}\text { Pulmonary: } \\
\text { ventilation }\end{array}$ \\
\hline Duration & Minutes to hours & Days to weeks & Days to weeks & Days to weeks \\
\hline Anticoagulation & $\begin{array}{l}\text { Very high-dose } \\
\text { heparin }\end{array}$ & Low-dose heparin & Low-dose or no heparin & Low-dose heparin \\
\hline Reversal & Protamine & No & No & No \\
\hline Air-blood interface & Yes & No & No & No \\
\hline
\end{tabular}

hemodilution can be employed in $\mathrm{CPB}$ and could lead to increased neutrophil activation and therefore SIRS [66, 67]. Finally, surgical trauma and the presence of blood-air interface due to cardiotomy suctioning, venting of blood, and venous reservoirs, which are incorporated in the circuit contribute to the inflammatory response [68].

\section{CPB and postoperative pulmonary dysfunction}

The impact of $\mathrm{CPB}$ on postoperative lung function has been debated. Traditional strategies of no MV during $\mathrm{CPB}$ might induce pulmonary dysfunction, due to development of micro-atelectasis, hydrostatic pulmonary edema, and ischemic lung injury secondary to reduction in bronchial artery flow [69]. Furthermore, ECLS-induced inflammation has been associated with pulmonary dysfunction. In adults undergoing CPB, IL-8 levels in the bronchoalveolar lavage were significantly correlated to arterial oxygenation and intrapulmonary shunt at the end of the surgery [70]. Moreover, the length of MV was longer in patients with an exaggerated inflammatory response to CPB [71]. Finally, postoperative concentration of IL-8 was higher in patients ventilated for more than 24 $\mathrm{h}$ in comparison to patients ventilated for less than $24 \mathrm{~h}$ [72].

Nonetheless, it has been suggested that post-CPB pulmonary dysfunction might be triggered by anesthesia or surgical technique. In patients with good ventricular function and without prior pulmonary diseases, coronary artery bypass on or off pump caused a similar degree of postoperative pulmonary dysfunction [73]. In addition, it has been speculated that the similar left atrium/right atrium ratio of leukocyte count in ventilated and non-ventilated patients during $\mathrm{CPB}$ reduces the possibility of the inflammatory response accounting for difference in the incidence of lung injury [74]

\section{Clinical implications of ECLS-associated inflammatory response}

Several studies demonstrated a considerable association between inflammation and outcome during ECLS in its different configurations. In neonates undergoing CPB, Interlukin 6 (IL-6) and IL-8 concentrations correlated with postoperative myocardial dysfunction [75], lactate concentrations, blood product administration, duration of $\mathrm{MV}$, and ICU and hospital length of stay [76, 77]. Moreover, in adults post-cardiac surgery, increased IL-6 levels after CPB were predictive of infection in patients with impaired left ventricular function [78], and preoperative IL-8 concentrations correlated with prolonged postoperative MV [79]. In addition, one specific genetic polymorphism of IL-6 was associated with acute lung injury [80].

During veno-venous extracorporeal membrane oxygenation (VV-ECMO) for severe ARDS, IL-6, IL-8, and tumor necrosis factor- $\alpha$ (TNF- $\alpha$ ) levels were associated with an 
increased risk of in-hospital mortality [25]. IL-6 levels were persistently increased in non-survivors among a mixed group of patients undergoing VV-ECMO and VA-ECMO [81]. Furthermore, higher levels of TNF- $\alpha$ have been correlated with mortality in neonates undergoing VV- or VA-ECMO [23, 52]. Of note, IL-6 was identified as a potentially useful prognostic marker for mortality during ECMO support [81], pulmonary dysfunction after $\mathrm{CPB}$ [82], and acute kidney injury after cardiac surgery, both in children [83] and in adults [84].

Greater release of IL-10 after CPB was associated with improved cardiac index and pulmonary gas exchange [85] and increased chance of survival following cardiogenic shock in adults supported with ECMO [86]. Additionally, IL-10 levels in ARDS patients correlated with severity of illness and predicted unsuccessful ECMO weaning and mortality [87].

\section{Potential therapeutic interventions in ECLS-induced inflammation}

A number of different strategies, including pharmacologic agents and non-pharmacologic interventions (i.e., innovative surgical techniques, ECLS circuit modifications, the conduction of anesthesia and ventilation), have been evaluated in experimental [88] and clinical trials $[33,89]$ with the aim of minimizing the impact of ECLS-related systemic inflammation on patients' outcome in pediatric [89, 90] and adult patients [91]. However, the impact of these strategies on the post-ECLS clinical course has been conflicting.

Although the administration of steroids during pediatric cardiac surgery has been associated with the attenuation of CPB-induced inflammation [89], their impact on postoperative clinical outcome remains modest [92]. The administration of steroids was associated with a reduction in postoperative infection and duration of postoperative MV and length of stay, but no beneficial effects on mortality and organ complications in adult cardiac surgery patients have been reported [93, 94].

Preoperative statin therapy was associated with a reduction in post-CPB inflammation [95, 96] and an improvement in morbidity and mortality after cardiac surgery [97-99]. However, a recent meta-analysis of randomized control trials (RCTs) found no evidence of benefit for patients' outcomes [100]. Patients with high preoperative IL-6 levels might be the best candidates for the preemptive administration of statins in cardiac surgery with CPB [101]. Other anti-inflammatory pharmacologic strategies, such as protease inhibitors (i.e., sivelestat, ulinastatin, aprotinin) [102-104] and milrinone [105], have been associated with improved postoperative clinical outcomes, although additional studies are needed to provide a better perspective regarding future applications.

Monoclonal antibodies have been studied as modulators of ECLS-induced inflammation. A novel inhibitory antibody against factor XIIa has been shown to reduced inflammation in ex vivo and animal models of ECMO [106]. Moreover, human monoclonal antibody directed at $\mathrm{C} 5$ significantly inhibited neutrophil activation in a model of simulated extracorporeal circuit (ECC) [107]. Mesenchymal stromal cells (MSC) therapy infusion in an animal model of CPB significantly reduced inflammatory cytokines within $3 \mathrm{~h}$ and subsequently reduced the harm associated with ischemia-reperfusion injury [108]. Promising results have also been shown with hemoadsorption during CPB [109] and ECMO [110]. However, all these therapeutic options remain experimental. 
Many technical modifications of the $\mathrm{CPB}$ circuit and surgical procedures were implemented to minimize systemic inflammation secondary to the activation of blood components after contact with the CPB circuit and pulmonary dysfunction after ischemia-reperfusion injury [90, 91]. A minimized extracorporeal circulation system [111] and the circuit coating with poly-2-methoxyethyl acrylate [112] or heparin [113] have been associated with a decrease in the systemic inflammatory response, thus potentially improving organ function after cardiac surgery. By reducing the ischemic insult to the lungs and inflammatory activation, pulmonary perfusion during CPB may decrease systemic inflammatory response and have a protective effect on the lungs [114-117]. However, robust evidence for any beneficial effects is lacking according to a recent meta-analysis [118].

\section{ECLS as a therapy for systemic inflammation}

Despite the fact that different modalities of ECLS have been implicated in driving an intense inflammatory response, ECLS can also be employed to offset it. By replacing the function of the heart or the lung, ECLS may result into a direct reduction of inflammation due for instance to improved perfusion and gas exchange or may allow the reduction of the pro-inflammatory "stress" induced by other life support means, such as MV, with an indirect effect on treating systemic inflammation.

\section{ARDS, VV-ECMO, and $\mathrm{ECCO}_{2} \mathrm{R}$}

In ARDS, pulmonary and systemic inflammation exacerbated by high MV settings, the so-called ventilator-induced lung injury, can be reduced by a lung-protective ventilation strategy [12], which has been demonstrated to increase patients' survival [119]. In an interesting recent observational trial, the initiation of VV-ECMO support in mechanically ventilated patients for ARDS was associated with a remarkable decrease in cytokine levels, potentially explained by the achievement of "lung rest" with less alveolar stress and strain [25].

Recently, the hypothesis that the implementation of ultra-protective MV may allow the achievement of minimal alveolar stress and strain, thus further reducing pulmonary and systemic inflammation in ARDS, has been addressed in experimental and observational clinical studies utilizing different ECLS strategies [120-122]. The use of $\mathrm{ECCO}_{2} \mathrm{R}$ has been reported to significantly reduce ARDS patients' inflammatory response [123, 124]. In an interesting proof-of-concept clinical study, patient with ARDS with high plateau airway pressure despite the delivery of protective MV with tidal volumes of 6 $\mathrm{cc} / \mathrm{kg}$ of predicted body weight were treated with $\mathrm{ECCO}_{2} \mathrm{R}$ for 3 days in order to further decrease tidal volumes and alveolar distending pressures. $\mathrm{ECCO}_{2} \mathrm{R}$ allowed the tidal volume to be decreased to less than $4 \mathrm{cc} / \mathrm{kg}$ of predicted body weight with the consequent significant reduction of the plateau airway pressure, while maintaining normal $\mathrm{pH}$ and $\mathrm{PaCO}_{2}$. Reduction in the MV intensity resulted in the decrease of alveolar overdistension, as demonstrated by CT scan imaging, and in the significant decreases of the bronchoalveolar inflammatory cytokines IL-6, IL-8, IL-1b, and IL-1Ra [124]. These results were confirmed in a more recent randomized controlled trial that, comparing ultra-protective $\mathrm{MV}$ facilitated by $\mathrm{ECCO}_{2} \mathrm{R}$ to conventional lung-protective ventilation, resulted in significant reduction in IL-6 within $24 \mathrm{~h}$ of initiation of pumpless 
arterio-venous $\mathrm{ECCO}_{2} \mathrm{R}$, but no effect on ventilator-free days or mortality [125]. However, rigorous clinical trials on this topic are needed before this approach can be recommended in clinical practice [126-128].

\section{Mechanical ventilation during CPB}

Although the impact of protective MV during CPB on cytokine levels, pulmonary function, and clinical outcomes is still controversial [129-131], most studies described its beneficial effect on post-CPB systemic inflammatory response [132-135] and lung function [74, 136], thereby potentially improving clinical outcomes [74]. For example, in adult patients undergoing CPB, IL-6 and IL-8 levels in the bronchoalveolar lavage fluid and plasma were higher with high tidal volume/low positive end-expiratory pressure than with low tidal volume/high positive end-expiratory pressure [132]. However, the interesting results of a pilot randomized controlled trial, comparing MV versus no MV during $\mathrm{CPB}$, showed that the group treated with MV had less pulmonary edema and shorter overall duration of MV [74]. It has been proposed that this benefit derives from the partial preservation of bronchial arterial flow. Despite a recent meta-analysis of randomized controlled trials showing that ventilation during $\mathrm{CPB}$ may improve post-CPB oxygenation and gas exchange [137], the positive effects of the designated MV techniques are probably short-term and with a questionable impact on the clinical outcome [137, 138].

\section{VA-ECMO and cardiogenic shock}

Institution of ECLS has been associated with reduction inflammation in patients with cardiogenic shock. This was reported to result in hemodynamic improvement in patients with left ventricular assist device used for cardiogenic shock [139]. Furthermore, a significant reduction in the levels of IL-6 and IL-10 was reported in patients following institution of VA-ECMO for post-cardiotomy syndrome and myocarditis [53]. The resultant hemodynamic stability was theorized to lead to improved end-organ perfusion and contributed to recovery from multiple organ failure. Moreover, the use of heparin-coated biocompatible circuits was thought to minimize blood-material interaction and result in reduction of ECMO-induced systemic inflammation.

\section{Conclusions}

Critical illness-associated inflammatory process is complex. It can be secondary to acute illness or due to complex ICU therapeutic interventions. ECLS can induce an inflammatory process that has been associated with morbidity and mortality. On the other hand, it can offer a therapeutic benefit in facilitating lung and cardiac support, which might limit the determinants of inflammation. In the future, the development of progressively more advanced ECLS technology will certainly provide a safer means of advanced life support with potentially higher chances to demonstrate their therapeutic benefit.

\section{Abbreviations}

CPB: Cardiopulmonary bypass; ECC: Extracorporeal circuit; $\mathrm{ECCO}_{2} \mathrm{R}$ : Extracorporeal carbon dioxide removal; ECLS: Extracorporeal life support; ICU: Intensive care unit; IL-10: Interlukin-10; IL-6: Interlukin-6; IL-8: Interleukin-8; MV: Mechanical ventilation; SIRS: Systemic inflammatory response syndrome; TF: Tissue factor; TNF-a: Tumor necrosis factor-alpha; VA-ECMO: Veno-arterial extracorporeal membrane oxygenation; W-ECMO: Veno-venous extracorporeal membrane oxygenation 
Acknowledgements

Not applicable

\section{Funding}

This article did not receive sponsorship for publication.

\section{Availability of data and materials}

Not applicable.

\section{About this supplement}

This articles has been published as part of Intensive Care Medicine Experimental Volume 7 Supplement 1 2019: Proceedings from the Third International Symposium on Acute Pulmonary Injury and Translational Research (INSPIRES III). The full contents of the supplement are available at <https://icm-experimental.springeropen.com/articles/ supplements/volume-7-supplement-1>

\section{Authors' contributions}

AA conceived the review, performed the literature review, drafted the first draft of the manuscript, and revised the manuscript. TP performed the literature review, drafted the manuscript, and revised the manuscript. LDS revised the manuscript for important intellectual content. All authors read and approved the final manuscript.

\section{Ethics approval and consent to participate}

Not applicable

\section{Consent for publication}

Not applicable

\section{Competing interests}

The authors declare that they have no competing interests.

\section{Publisher's Note}

Springer Nature remains neutral with regard to jurisdictional claims in published maps and institutional affiliations.

\section{Author details}

${ }^{1}$ Adult Critical Care Medicine Fellowship Program, University of Toronto, Toronto, Canada. ${ }^{2}$ Al-Amiri Hospital, Ministry of Health, Kuwait City, Kuwait. ${ }^{3}$ Interdepartmental Division of Critical Care Medicine, Toronto General Hospital, University of Toronto, Toronto, Canada. ${ }^{4}$ Toronto General Hospital, 585 University Avenue, PMB 11-122, Toronto, Ontario M5G 2 N2, Canada.

Received: 8 April 2019 Accepted: 22 April 2019

Published: 25 July 2019

\section{References}

1. Pierce A, Pittet JF (2014) Inflammatory response to trauma: implications for coagulation and resuscitation. Curr Opin Anaesthesiol 27:246-252.

2. Bosmann M, Ward PA (2013) The inflammatory response in sepsis. Trends Immunol 34:129-136.

3. Meduri GU, Headley S, Kohler G, Stentz F, Tolley E, Umberger R, Leeper K (1995) Persistent elevation of inflammatory cytokines predicts a poor outcome in ARDS. Plasma IL-1 beta and IL-6 levels are consistent and efficient predictors of outcome over time. Chest 107:1062-1073.

4. Roumen RM, Hendriks T, van der Ven-Jongekrijg J, Nieuwenhuijzen GA, Sauerwein RW, van der Meer JW, Goris RJ (1993) Cytokine patterns in patients after major vascular surgery, hemorrhagic shock, and severe blunt trauma. Relation with subsequent adult respiratory distress syndrome and multiple organ failure. Ann Surg 218:769-776.

5. Baughman RP, Gunther KL, Rashkin MC, Keeton DA, Pattishall EN (1996) Changes in the inflammatory response of the lung during acute respiratory distress syndrome: prognostic indicators. Am J Respir Crit Care Med 154:76-81.

6. Headley AS, Tolley E, Meduri GU (1997) Infections and the inflammatory response in acute respiratory distress syndrome. Chest 111:1306-1321.

7. Jawa RS, Anillo S, Huntoon K, Baumann H, Kulaylat M (2011) Interleukin-6 in surgery, trauma, and critical care part II: clinical implications. J Intensive Care Med 26:73-87.

8. Antonelli M (1999) Sepsis and septic shock: pro-inflammatory or anti-inflammatory state? J Chemother 11:536-540.

9. Goris RJ, te Boekhorst TP, Nuytinck JK, Gimbrere JS (1985) Multiple-organ failure. Generalized autodestructive inflammation? Arch Surg 120:1109-1115.

10. Baue AE, Chaudry IH (1980) Prevention of multiple systems failure. Surg Clin North Am 60:1167-1178.

11. Goris RJ, Gimbrere JS, van Niekerk JL, Schoots FJ, Booy LH (1982) Early osteosynthesis and prophylactic mechanical ventilation in the multitrauma patient. J Trauma 22:895-903.

12. Ranieri VM, Suter PM, Tortorella C, De Tullio R, Dayer JM, Brienza A, Bruno F, Slutsky AS (1999) Effect of mechanical ventilation on inflammatory mediators in patients with acute respiratory distress syndrome: a randomized controlled trial. JAMA 282:54-61.

13. Parsons PE, Eisner MD, Thompson BT, Matthay MA, Ancukiewicz M, Bernard GR, Wheeler AP, Network NARDSCT (2005) Lower tidal volume ventilation and plasma cytokine markers of inflammation in patients with acute lung injury. Crit Care Med 33:1-6 discussion 230-232. 
14. Meduri GU, Golden E, Freire AX, Taylor E, Zaman M, Carson SJ, Gibson M, Umberger R (2007) Methylprednisolone infusion in early severe ARDS: results of a randomized controlled trial. Chest 131:954-963.

15. Fortenberry JDLR (2017) The history and development of extracorporeal support. In: Brogan TVLL, Lorusso R, MacLaren G, Peek G (eds) Extracorporeal life support: the ELSO Red Book 5th ed. Extracorporeal Life Support Organization, Ann Arbor, pp 1-15.

16. Hill JD, O'Brien TG, Murray JJ, Dontigny L, Bramson ML, Osborn JJ, Gerbode F (1972) Prolonged extracorporeal oxygenation for acute post-traumatic respiratory failure (shock-lung syndrome). Use of the Bramson membrane lung. N Engl J Med 286:629-634.

17. Zapol WM, Snider MT, Hill JD, Fallat RJ, Bartlett RH, Edmunds LH, Morris AH, Peirce EC 2nd, Thomas AN, Proctor HJ, Drinker PA, Pratt PC, Bagniewski A, Miller RG Jr (1979) Extracorporeal membrane oxygenation in severe acute respiratory failure. A randomized prospective study. JAMA 242:2193-2196.

18. Morris AH, Wallace CJ, Menlove RL, Clemmer TP, Orme JF Jr, Weaver LK, Dean NC, Thomas F, East TD, Pace NL, Suchyta MR, Beck E, Bombino M, Sittig DF, Bohm S, Hoffmann B, Becks H, Butler S, Pearl J, Rasmusson B (1994) Randomized clinical trial of pressure-controlled inverse ratio ventilation and extracorporeal $\mathrm{CO} 2$ removal for adult respiratory distress syndrome. Am J Respir Crit Care Med 149:295-305.

19. Thiagarajan RR, Barbaro RP, Rycus PT, McMullan DM, Conrad SA, Fortenberry JD, Paden ML, centers Em (2017) Extracorporeal Life Support Organization Registry International Report 2016. ASAIO J 63:60-67.

20. Wang S, Krawiec C, Patel S, Kunselman AR, Song J, Lei F, Baer LD, Undar A (2015) Laboratory evaluation of hemolysis and systemic inflammatory response in neonatal nonpulsatile and pulsatile extracorporeal life support systems. Artif Organs 39:774-781.

21. MC IRB, Timpa JG, Kurundkar AR, Holt DW, Kelly DR, Hartman YE, Neel ML, Karnatak RK, Schelonka RL, Anantharamaiah GM, Killingsworth CR, Maheshwari A (2010) Plasma concentrations of inflammatory cytokines rise rapidly during ECMOrelated SIRS due to the release of preformed stores in the intestine. Lab Invest 90:128-139.

22. Hirthler M, Simoni J, Dickson M (1992) Elevated levels of endotoxin, oxygen-derived free radicals, and cytokines during extracorporeal membrane oxygenation. J Pediatr Surg 27:1199-1202.

23. Plotz FB, van Oeveren W, Bartlett RH, Wildevuur CR (1993) Blood activation during neonatal extracorporeal life support. J Thorac Cardiovasc Surg 105:823-832.

24. Liu CH, Kuo SW, Hsu LM, Huang SC, Wang CH, Tsai PR, Chen YS, Jou TS, Ko WJ (2016) Peroxiredoxin 1 induces inflammatory cytokine response and predicts outcome of cardiogenic shock patients necessitating extracorporeal membrane oxygenation: an observational cohort study and translational approach. J Transl Med 14:114.

25. Burrell AJC, Lubnow M, Enger TB, Nanjayya VB, Philipp A, Malfertheiner MV, Lunz D, Bein T, Pellegrino VA, Muller T (2017) The impact of venovenous extracorporeal membrane oxygenation on cytokine levels in patients with severe acute respiratory distress syndrome: a prospective, observational study. Crit Care Resusc 19:37-44.

26. Griffith DM, Lewis S, Rossi AG, Rennie J, Salisbury L, Merriweather JL, Templeton K, Walsh TS, Investigators R (2016) Systemic inflammation after critical illness: relationship with physical recovery and exploration of potential mechanisms. Thorax 71:820-829.

27. Wan S, Marchant A, DeSmet JM, Antoine M, Zhang H, Vachiery JL, Goldman M, Vincent JL, LeClerc JL (1996) Human cytokine responses to cardiac transplantation and coronary artery bypass grafting. J Thorac Cardiovasc Surg 111:469-477.

28. Kaneda H, Waddell TK, de Perrot M, Bai XH, Gutierrez C, Arenovich T, Chaparro C, Liu M, Keshavjee S (2006) Preimplantation multiple cytokine mRNA expression analysis of donor lung grafts predicts survival after lung transplantation in humans. Am J Transplant 6:544-551.

29. Mathur A, Baz M, Staples ED, Bonnell M, Speckman JM, Hess PJ Jr, Klodell CT, Knauf DG, Moldawer LL, Beaver TM (2006) Cytokine profile after lung transplantation: correlation with allograft injury. Ann Thorac Surg 81:1844-1849 discussion 1849-1850.

30. Langer F, Schramm R, Bauer M, Tscholl D, Kunihara T, Schafers HJ (2004) Cytokine response to pulmonary thromboendarterectomy. Chest 126:135-141.

31. Slutsky AS, Ranieri VM (2014) Ventilator-induced lung injury. N Engl J Med 370:980.

32. Davies MG, Hagen PO (1997) Systemic inflammatory response syndrome. Br J Surg 84:920-935.

33. Millar JE, Fanning JP, McDonald Cl, McAuley DF, Fraser JF (2016) The inflammatory response to extracorporeal membrane oxygenation (ECMO): a review of the pathophysiology. Crit Care 20:387.

34. Wendel HP, Scheule AM, Eckstein FS, Ziemer G (1999) Haemocompatibility of paediatric membrane oxygenators with heparin-coated surfaces. Perfusion 14:21-28.

35. Wachtfogel YT, Hack CE, Nuijens JH, Kettner C, Reilly TM, Knabb RM, Bischoff R, Tschesche H, Wenzel H, Kucich U et al (1995) Selective kallikrein inhibitors alter human neutrophil elastase release during extracorporeal circulation. Am J Physiol 268:H1352-H1357.

36. Cugno M, Nussberger J, Biglioli P, Giovagnoni MG, Gardinali M, Agostoni A (1999) Cardiopulmonary bypass increases plasma bradykinin concentrations. Immunopharmacology 43:145-147.

37. Morgan EN, PohIman TH, Vocelka C, Farr A, Lindley G, Chandler W, Griscavage-Ennis JM, Verrier ED (2003) Nuclear factor kappaB mediates a procoagulant response in monocytes during extracorporeal circulation. J Thorac Cardiovasc Surg 125:165-171.

38. Szotowski B, Antoniak S, Poller W, Schultheiss HP, Rauch U (2005) Procoagulant soluble tissue factor is released from endothelial cells in response to inflammatory cytokines. Circ Res 96:1233-1239.

39. Wehlin L, Vedin J, Vaage J, Lundahl J (2004) Activation of complement and leukocyte receptors during on- and off pump coronary artery bypass surgery. Eur J Cardiothorac Surg 25:35-42.

40. Vallhonrat H, Swinford RD, Ingelfinger JR, Williams WW, Ryan DP, Tolkoff-Rubin N, Cosimi AB, Pascual M (1999) Rapid activation of the alternative pathway of complement by extracorporeal membrane oxygenation. ASAIO J 45:113-114.

41. Moen O, Fosse E, Braten J, Andersson C, Fagerhol MK, Venge P, Hogasen K, Mollnes TE (1994) Roller and centrifugal pumps compared in vitro with regard to haemolysis, granulocyte and complement activation. Perfusion 9:109-117.

42. Hocker JR, Wellhausen SR, Ward RA, Simpson PM, Cook LN (1991) Effect of extracorporeal membrane oxygenation on leukocyte function in neonates. Artif Organs 15:23-28. 
43. Gardinali M, Cicardi M, Frangi D, Bergamaschini L, Gallazzi M, Gattinoni L, Agostoni A (1985) Studies of complement activation in ARDS patients treated by long-term extracorporeal CO2 removal. Int J Artif Organs 8:135-140.

44. Chenoweth DE, Cooper SW, Hugli TE, Stewart RW, Blackstone EH, Kirklin JW (1981) Complement activation during cardiopulmonary bypass: evidence for generation of C3a and C5a anaphylatoxins. N Engl J Med 304:497-503.

45. Gemmell CH, Ramirez SM, Yeo EL, Sefton MV (1995) Platelet activation in whole blood by artificial surfaces: identification of platelet-derived microparticles and activated platelet binding to leukocytes as material-induced activation events. J Lab Clin Med 125:276-287.

46. Bick RL (1976) Alterations of hemostasis associated with cardiopulmonary bypass: pathophysiology, prevention, diagnosis, and management. Semin Thromb Hemost 3:59-82.

47. Weerasinghe A, Taylor KM (1998) The platelet in cardiopulmonary bypass. Ann Thorac Surg 66:2145-2152.

48. Cheung PY, Sawicki G, Salas E, Etches PC, Schulz R, Radomski MW (2000) The mechanisms of platelet dysfunction during extracorporeal membrane oxygenation in critically ill neonates. Crit Care Med 28:2584-2590.

49. Maugeri N, Brambilla M, Camera M, Carbone A, Tremoli E, Donati MB, de Gaetano G, Cerletti C (2006) Human polymorphonuclear leukocytes produce and express functional tissue factor upon stimulation. J Thromb Haemost 4: 1323-1330.

50. Duffy MJ, Mullan BA, Craig TR, Shyamsundar M, MacSweeney RE, Thompson G, Stevenson M, McAuley DF (2011) Impaired endothelium-dependent vasodilatation is a novel predictor of mortality in intensive care. Crit Care Med 39. 629-635.

51. Boyle EM Jr, Pohlman TH, Johnson MC, Verrier ED (1997) Endothelial cell injury in cardiovascular surgery: the systemic inflammatory response. Ann Thorac Surg 63:277-284.

52. Fortenberry JD, Bhardwaj V, Niemer P, Cornish JD, Wright JA, Bland L (1996) Neutrophil and cytokine activation with neonatal extracorporeal membrane oxygenation. J Pediatr 128:670-678.

53. Kawahito K, Misawa Y, Fuse K (1998) Extracorporeal membrane oxygenation support and cytokines. Ann Thorac Surg 65: 1192-1193.

54. Wachtfogel YT, Kucich U, Hack CE, Gluszko P, Niewiarowski S, Colman RW, Edmunds LH Jr (1993) Aprotinin inhibits the contact, neutrophil, and platelet activation systems during simulated extracorporeal perfusion. J Thorac Cardiovasc Surg 106:1-9 discussion 9-10.

55. Graulich J, Walzog B, Marcinkowski M, Bauer K, Kossel H, Fuhrmann G, Buhrer C, Gaehtgens P, Versmold HT (2000) Leukocyte and endothelial activation in a laboratory model of extracorporeal membrane oxygenation (ECMO). Pediatr Res 48:679-684.

56. Riddington DW, Venkatesh B, Boivin CM, Bonser RS, Elliott TS, Marshall T, Mountford PJ, Bion JF (1996) Intestinal permeability, gastric intramucosal pH, and systemic endotoxemia in patients undergoing cardiopulmonary bypass. JAMA 275:1007-1012.

57. Kurundkar AR, Killingsworth CR, Mcllwain RB, Timpa JG, Hartman YE, He D, Karnatak RK, Neel ML, Clancy JP, Anantharamaiah GM, Maheshwari A (2010) Extracorporeal membrane oxygenation causes loss of intestinal epithelial barrier in the newborn piglet. Pediatr Res 68:128-133.

58. Jirik FR, Podor TJ, Hirano T, Kishimoto T, Loskutoff DJ, Carson DA, Lotz M (1989) Bacterial lipopolysaccharide and inflammatory mediators augment IL-6 secretion by human endothelial cells. J Immunol 142:144-147.

59. Jansen NJ, van Oeveren W, Gu YJ, van Vliet MH, Eijsman L, Wildevuur CR (1992) Endotoxin release and tumor necrosis factor formation during cardiopulmonary bypass. Ann Thorac Surg 54:744-747 discussion 747-748.

60. Ernofsson M, Thelin S, Siegbahn A (1997) Monocyte tissue factor expression, cell activation, and thrombin formation during cardiopulmonary bypass: a clinical study. J Thorac Cardiovasc Surg 113:576-584.

61. Yang J, Schall C, Smith D, Kreuser L, Zamberlan M, King K, Gajarski R (2009) HLA sensitization in pediatric pre-transplant cardiac patients supported by mechanical assist devices: the utility of Luminex. J Heart Lung Transplant 28:123-129.

62. Hong BJ, Delaney M, Guynes A, Warner P, McMullan DM, Kemna MS, Boucek RJ, Law YM (2014) Human leukocyte antigen sensitization in pediatric patients exposed to mechanical circulatory support. ASAIO J 60:317-321.

63. Hayes D Jr, Preston TJ, Kirkby S, Nicol KK (2013) Human leukocyte antigen sensitization in lung transplant candidates supported by extracorporeal membrane oxygenation. Am J Respir Crit Care Med 188:627-628.

64. Warren OJ, Smith AJ, Alexiou C, Rogers PL, Jawad N, Vincent C, Darzi AW, Athanasiou T (2009) The inflammatory response to cardiopulmonary bypass: part 1--mechanisms of pathogenesis. J Cardiothorac Vasc Anesth 23:223-231.

65. Bruins $\mathrm{P}$, te Velthuis $\mathrm{H}$, Eerenberg-Belmer AJ, Yazdanbakhsh AP, de Beaumont EM, Eijsman L, Trouwborst A, Hack CE (2000) Heparin-protamine complexes and C-reactive protein induce activation of the classical complement pathway: studies in patients undergoing cardiac surgery and in vitro. Thromb Haemost 84:237-243.

66. Gourlay T, Samartzis I, Taylor KM (2003) The effect of haemodilution on blood-biomaterial contact-mediated CD11b expression on neutrophils: ex vivo studies. Perfusion 18:87-93.

67. DeFoe GR, Ross CS, Olmstead EM, Surgenor SD, Fillinger MP, Groom RC, Forest RJ, Pieroni JW, Warren CS, Bogosian ME, Krumholz CF, Clark C, Clough RA, Weldner PW, Lahey SJ, Leavitt BJ, Marrin CA, Charlesworth DC, Marshall P, O'Connor GT (2001) Lowest hematocrit on bypass and adverse outcomes associated with coronary artery bypass grafting. Northern New England Cardiovascular Disease Study Group. Ann Thorac Surg 71:769-776.

68. Gabel J, Westerberg M, Bengtsson A, Jeppsson A (2013) Cell salvage of cardiotomy suction blood improves the balance between pro- and anti-inflammatory cytokines after cardiac surgery. Eur J Cardiothorac Surg 44:506-511.

69. Asimakopoulos G, Smith PL, Ratnatunga CP, Taylor KM (1999) Lung injury and acute respiratory distress syndrome after cardiopulmonary bypass. Ann Thorac Surg 68:1107-1115.

70. Kotani N, Hashimoto H, Sessler DI, Muraoka M, Wang JS, O'Connor MF, Matsuki A (2000) Neutrophil number and interleukin-8 and elastase concentrations in bronchoalveolar lavage fluid correlate with decreased arterial oxygenation after cardiopulmonary bypass. Anesth Analg 90:1046-1051.

71. Holmes JH, Connolly NC, Paull DL, Hill ME, Guyton SW, Ziegler SF, Hall RA (2002) Magnitude of the inflammatory response to cardiopulmonary bypass and its relation to adverse clinical outcomes. Inflamm Res 51:579-586.

72. Rothenburger M, Soeparwata R, Deng MC, Berendes E, Schmid C, Tjan TD, Wilhelm MJ, Erren M, Bocker D, Scheld HH (2001) The impact of anti-endotoxin core antibodies on endotoxin and cytokine release and ventilation time after cardiac surgery. J Am Coll Cardiol 38:124-130. 
73. Cox CM, Ascione R, Cohen AM, Davies IM, Ryder IG, Angelini GD (2000) Effect of cardiopulmonary bypass on pulmonary gas exchange: a prospective randomized study. Ann Thorac Surg 69:140-145.

74. John LC, Ervine IM (2008) A study assessing the potential benefit of continued ventilation during cardiopulmonary bypass. Interact Cardiovasc Thorac Surg 7:14-17.

75. Hovels-Gurich HH, Vazquez-Jimenez JF, Silvestri A, Schumacher K, Minkenberg R, Duchateau J, Messmer BJ, von Bernuth G, Seghaye MC (2002) Production of proinflammatory cytokines and myocardial dysfunction after arterial switch operation in neonates with transposition of the great arteries. J Thorac Cardiovasc Surg 124:811-820.

76. Allan CK, Newburger JW, McGrath E, Elder J, Psoinos C, Laussen PC, del Nido PJ, Wypij D, FX MG Jr (2010) The relationship between inflammatory activation and clinical outcome after infant cardiopulmonary bypass. Anesth Analg 111:1244-1251.

77. Mahle WT, Matthews E, Kanter KR, Kogon BE, Hamrick SE, Strickland MJ (2014) Inflammatory response after neonatal cardiac surgery and its relationship to clinical outcomes. Ann Thorac Surg 97:950-956.

78. Sander M, von Heymann C, von Dossow V, Spaethe C, Konertz WF, Jain U, Spies CD (2006) Increased interleukin-6 after cardiac surgery predicts infection. Anesth Analg 102:1623-1629.

79. Rothenburger M, Soeparwata R, Deng MC, Schmid C, Berendes E, Tjan TD, Wilhelm MJ, Erren M, Bocker D, Scheld HH (2001) Prediction of clinical outcome after cardiac surgery: the role of cytokines, endotoxin, and anti-endotoxin core antibodies. Shock 16(Suppl 1):44-50.

80. Wang JF, Bian JJ, Wan XJ, Zhu KM, Sun ZZ, Lu AD (2010) Association between inflammatory genetic polymorphism and acute lung injury after cardiac surgery with cardiopulmonary bypass. Med Sci Monit 16:CR260-CR265.

81. Risnes I, Wagner K, Ueland T, Mollnes T, Aukrust P, Svennevig J (2008) Interleukin-6 may predict survival in extracorporeal membrane oxygenation treatment. Perfusion 23:173-178.

82. Halter J, Steinberg J, Fink G, Lutz C, Picone A, Maybury R, Fedors N, DiRocco J, Lee HM, Nieman G (2005) Evidence of systemic cytokine release in patients undergoing cardiopulmonary bypass. J Extra Corpor Technol 37:272-277.

83. Dennen P, Altmann C, Kaufman J, Klein CL, Andres-Hernando A, Ahuja NH, Edelstein CL, Cadnapaphornchai MA, Keniston A, Faubel S (2010) Urine interleukin-6 is an early biomarker of acute kidney injury in children undergoing cardiac surgery. Crit Care 14:R181.

84. Musleh GS, Datta SS, Yonan NN, Grotte GJ, Prendergast BA, Hasan Rl, Deyrania AK (2009) Association of IL6 and IL10 with renal dysfunction and the use of haemofiltration during cardiopulmonary bypass. Eur I Cardiothorac Surg 35:511-514.

85. Giomarelli P, Scolletta S, Borrelli E, Biagioli B (2003) Myocardial and lung injury after cardiopulmonary bypass: role of interleukin (IL)-10. Ann Thorac Surg 76:117-123.

86. Hong T-H, Hu F-C, Kuo S-W, Ko W-J, Chow L-P, Hsu L-M, Huang S-C, Yu S-L, Chen Y-S (2015) Predicting outcome in patients under extracorporeal membrane oxygenation due to cardiogenic shock through dynamic change of lymphocytes and interleukins. IJC Metabolic \& Endocrine 7:36-44.

87. Liu CH, Kuo SW, Ko WJ, Tsai PR, Wu SW, Lai CH, Wang CH, Chen YS, Chen PL, Liu TT, Huang SC, Jou TS (2017) Early measurement of IL-10 predicts the outcomes of patients with acute respiratory distress syndrome receiving extracorporeal membrane oxygenation. Sci Rep 7:1021.

88. Liguori GR, Kanas AF, Moreira LF (2014) Managing the inflammatory response after cardiopulmonary bypass: review of the studies in animal models. Rev Bras Cir Cardiovasc 29:93-102.

89. Bronicki RA, Hall M (2016) Cardiopulmonary bypass-induced inflammatory response: pathophysiology and treatment. Pediatr Crit Care Med 17:S272-S278.

90. Durandy Y (2014) Minimizing systemic inflammation during cardiopulmonary bypass in the pediatric population. Artif Organs 38:11-18

91. Landis RC, Brown JR, Fitzgerald D, Likosky DS, Shore-Lesserson L, Baker RA, Hammon JW (2014) Attenuating the systemic inflammatory response to adult cardiopulmonary pypass: a critical review of the evidence base. J Extra Corpor Technol 46:197-211.

92. Scrascia G, Rotunno C, Guida P, Amorese L, Polieri D, Codazzi D, Paparella D (2014) Perioperative steroids administration in pediatric cardiac surgery: a meta-analysis of randomized controlled trials*. Pediatr Crit Care Med 15:435-442.

93. Dieleman JM, van Paassen J, van Dijk D, Arbous MS, Kalkman CJ, Vandenbroucke JP, van der Heijden GJ, Dekkers OM (2011) Prophylactic corticosteroids for cardiopulmonary bypass in adults. Cochrane Database Syst Rev 11:CD005566.

94. Dieleman JM, Nierich AP, Rosseel PM, van der Maaten JM, Hofland J, Diephuis JC, Schepp RM, Boer C, Moons KG, van Herwerden LA, Tijssen JG, Numan SC, Kalkman CJ, van Dijk D, Dexamethasone for Cardiac Surgery Study G (2012) Intraoperative high-dose dexamethasone for cardiac surgery: a randomized controlled trial. JAMA 308:1761-1767.

95. Morgan C, Zappitelli M, Gill P (2009) Statin prophylaxis and inflammatory mediators following cardiopulmonary bypass: a systematic review. Crit Care 13:R165.

96. Ozguler IM, Burma O, Uysal A, Akbulut H (2015) Rosuvastatin lowers systemic inflammatory response in coronary artery bypass graft accompanied by cardiopulmonary bypass surgery: a randomized controlled study. Clin Invest Med 38: E154-E163.

97. Clark LL, Ikonomidis JS, Crawford FA Jr, Crumbley A 3rd, Kratz JM, Stroud MR, Woolson RF, Bruce JJ, Nicholas JS, Lackland DT, Zile MR, Spinale FG (2006) Preoperative statin treatment is associated with reduced postoperative mortality and morbidity in patients undergoing cardiac surgery: an 8-year retrospective cohort study. J Thorac Cardiovasc Surg 131:679-685.

98. Collard CD, Body SC, Shernan SK, Wang S, Mangano DT, Multicenter Study of Perioperative Ischemia Research Group I, Ischemia R, Education Foundation I (2006) Preoperative statin therapy is associated with reduced cardiac mortality after coronary artery bypass graft surgery. J Thorac Cardiovasc Surg 132:392-400.

99. Virani SS, Nambi V, Lee W, Elayda M, Reul RM, Wilson JM, Ballantyne CM (2008) Does preoperative statin therapy improve outcomes in patients undergoing isolated cardiac valve surgery? Am J Cardiol 102:1235-1239.

100. Putzu A, Capelli B, Belletti A, Cassina T, Ferrari E, Gallo M, Casso G, Landoni G (2016) Perioperative statin therapy in cardiac surgery: a meta-analysis of randomized controlled trials. Crit Care 20:395.

101. Martinez-Comendador J, Alvarez JR, Sierra J, Teijeira E, Adrio B (2013) Preoperative statin therapy in cardiac surgery is more effective in patients who display preoperative activation of the inflammatory system. Tex Heart Inst J 40:42-49. 
102. Fujii M, Miyagi Y, Bessho R, Nitta T, Ochi M, Shimizu K (2010) Effect of a neutrophil elastase inhibitor on acute lung injury after cardiopulmonary bypass. Interact Cardiovasc Thorac Surg 10:859-862.

103. He S, Lin K, Ma R, Xu R, Xiao Y (2015) Effect of the urinary tryptin inhibitor ulinastatin on cardiopulmonary bypass-related inflammatory response and clinical outcomes: a meta-analysis of randomized controlled trials. Clin Ther 37:643-653.

104. Xu CE, Zou CW, Zhang MY, Guo L (2013) Effects of high-dose ulinastatin on inflammatory response and pulmonary function in patients with type-A aortic dissection after cardiopulmonary bypass under deep hypothermic circulatory arrest. J Cardiothorac Vasc Anesth 27:479-484.

105. Gong M, Lin XZ, Lu GT, Zheng $L$ (2012) Preoperative inhalation of milrinone attenuates inflammation in patients undergoing cardiac surgery with cardiopulmonary bypass. Med Princ Pract 21:30-35.

106. Larsson M, Rayzman V, Nolte MW, Nickel KF, Bjorkqvist J, Jamsa A, Hardy MP, Fries M, Schmidbauer S, Hedenqvist P, Broome M, Pragst I, Dickneite G, Wilson MJ, Nash AD, Panousis C, Renne T (2014) A factor Xlla inhibitory antibody provides thromboprotection in extracorporeal circulation without increasing bleeding risk. Sci Transl Med 6:222ra217.

107. Rinder CS, Rinder HM, Smith BR, Fitch JC, Smith MJ, Tracey JB, Matis LA, Squinto SP, Rollins SA (1995) Blockade of $\mathrm{C} 5 \mathrm{a}$ and $\mathrm{C} 5 \mathrm{~b}-9$ generation inhibits leukocyte and platelet activation during extracorporeal circulation. J Clin Invest 96:1564-1572.

108. Qiang Y, Liang G, Yu L (2016) Human amniotic mesenchymal stem cells alleviate lung injury induced by ischemia and reperfusion after cardiopulmonary bypass in dogs. Lab Invest 96:537-546.

109. Bernardi MH, Rinoesl H, Dragosits K, Ristl R, Hoffelner F, Opfermann P, Lamm C, Preissing F, Wiedemann D, Hiesmayr MJ, Spittler A (2016) Effect of hemoadsorption during cardiopulmonary bypass surgery - a blinded, randomized, controlled pilot study using a novel adsorbent. Crit Care 20:96.

110. Bruenger F, Kizner L, Weile J, Morshuis M, Gummert JF (2015) First successful combination of ECMO with cytokine removal therapy in cardiogenic septic shock: a case report. Int J Artif Organs 38:113-116.

111. Fromes Y, Gaillard D, Ponzio O, Chauffert M, Gerhardt MF, Deleuze P, Bical OM (2002) Reduction of the inflammatory response following coronary bypass grafting with total minimal extracorporeal circulation. Eur J Cardiothorac Surg 22: 527-533.

112. Ueyama K, Nishimura K, Nishina T, Nakamura T, Ikeda T, Komeda M (2004) PMEA coating of pump circuit and oxygenator may attenuate the early systemic inflammatory response in cardiopulmonary bypass surgery. ASAIO J 50: 369-372.

113. Mahmood S, Bilal H, Zaman M, Tang A (2012) Is a fully heparin-bonded cardiopulmonary bypass circuit superior to a standard cardiopulmonary bypass circuit? Interact Cardiovasc Thorac Surg 14:406-414.

114. Richter JA, Meisner H, Tassani P, Barankay A, Dietrich W, Braun SL (2000) Drew-Anderson technique attenuates systemic inflammatory response syndrome and improves respiratory function after coronary artery bypass grafting. Ann Thorac Surg 69:77-83.

115. Sievers HH, Freund-Kaas C, Eleftheriadis S, Fischer T, Kuppe H, Kraatz EG, Bechtel JF (2002) Lung protection during total cardiopulmonary bypass by isolated lung perfusion: preliminary results of a novel perfusion strategy. Ann Thorac Surg 74:1167-1172 discussion 1172.

116. Suzuki T, Ito T, Kashima I, Teruya K, Fukuda T (2001) Continuous perfusion of pulmonary arteries during total cardiopulmonary bypass favorably affects levels of circulating adhesion molecules and lung function. J Thorac Cardiovasc Surg 122:242-248.

117. Kiessling AH, Guo FW, Gokdemir Y, Thudt M, Reyher C, Scherer M, Beiras-Fernandez A, Moritz A (2014) The influence of selective pulmonary perfusion on the inflammatory response and clinical outcome of patients with chronic obstructive pulmonary disease undergoing cardiopulmonary bypass. Interact Cardiovasc Thorac Surg 18:732-739.

118. Buggeskov KB, Gronlykke L, Risom EC, Wei ML, Wetterslev J (2018) Pulmonary artery perfusion versus no perfusion during cardiopulmonary bypass for open heart surgery in adults. Cochrane Database Syst Rev 2:CD011098.

119. Acute Respiratory Distress Syndrome N, Brower RG, Matthay MA, Morris A, Schoenfeld D, Thompson BT, Wheeler A (2000) Ventilation with lower tidal volumes as compared with traditional tidal volumes for acute lung injury and the acute respiratory distress syndrome. N Engl J Med 342:1301-1308.

120. Iglesias M, Jungebluth P, Petit C, Matute MP, Rovira I, Martinez E, Catalan M, Ramirez J, Macchiarini P (2008) Extracorporeal lung membrane provides better lung protection than conventional treatment for severe postpneumonectomy noncardiogenic acute respiratory distress syndrome. J Thorac Cardiovasc Surg 135:1362-1371.

121. Grasso S, Stripoli T, Mazzone P, Pezzuto M, Lacitignola L, Centonze P, Guarracino A, Esposito C, Herrmann P, Quintel M, Trerotoli P, Bruno F, Crovace A, Staffieri F (2014) Low respiratory rate plus minimally invasive extracorporeal Co2 removal decreases systemic and pulmonary inflammatory mediators in experimental Acute Respiratory Distress Syndrome. Crit Care Med 42:e451-e460.

122. Guldner A, Kiss T, Bluth T, Uhlig C, Braune A, Carvalho N, Quast T, Rentzsch I, Huhle R, Spieth P, Richter T, Saddy F, Rocco PR, Kasper M, Koch T, Pelosi P, de Abreu MG (2015) Effects of ultraprotective ventilation, extracorporeal carbon dioxide removal, and spontaneous breathing on lung morphofunction and inflammation in experimental severe acute respiratory distress syndrome. Anesthesiology 122:631-646.

123. Iglesias M, Martinez E, Badia JR, Macchiarini P (2008) Extrapulmonary ventilation for unresponsive severe acute respiratory distress syndrome after pulmonary resection. Ann Thorac Surg 85:237-244 discussion 244.

124. Terragni PP, Del Sorbo L, Mascia L, Urbino R, Martin EL, Birocco A, Faggiano C, Quintel M, Gattinoni L, Ranieri VM (2009) Tidal volume lower than $6 \mathrm{ml} / \mathrm{kg}$ enhances lung protection: role of extracorporeal carbon dioxide removal. Anesthesiology 111:826-835.

125. Bein T, Weber-Carstens S, Goldmann A, Muller T, Staudinger T, Brederlau J, Muellenbach R, Dembinski R, Graf BM, Wewalka M, Philipp A, Wernecke KD, Lubnow M, Slutsky AS (2013) Lower tidal volume strategy ( approximately $3 \mathrm{ml} / \mathrm{kg}$ ) combined with extracorporeal $\mathrm{CO} 2$ removal versus 'conventional' protective ventilation $(6 \mathrm{ml} / \mathrm{kg})$ in severe ARDS: the prospective randomized Xtravent-study. Intensive Care Med 39:847-856.

126. Fan E, Brodie D, Slutsky AS (2017) Fifty Years of Research in ARDS. Mechanical ventilation during extracorporeal support for acute respiratory distress syndrome. For Now, a Necessary Evil. Am J Respir Crit Care Med 195:1137-1139.

127. Belfast Health and social care Trust (2016) Protective ventilation with venovenous lung assist in respiratory failure (REST) [http://clinicaltrials.gov/ct2/show/NCT02654327] (NLM Identifier: NCT02654327). 
128. European Society of Intensive Care Medicine (2014) Strategy of ultraprotective lung ventilation with extracorporeal CO2 removal for new-onset moderate to severe ARDS (SUPERNOVA) [http://clinicaltrials.gov/ct2/show/NCT02282657] (NLM Identifier: NCT02282657).

129. Koner O, Celebi S, Balci H, Cetin G, Karaoglu K, Cakar N (2004) Effects of protective and conventional mechanical ventilation on pulmonary function and systemic cytokine release after cardiopulmonary bypass. Intensive Care Med 30 620-626.

130. Gagnon J, Laporta D, Beique F, Langlois Y, Morin JF (2010) Clinical relevance of ventilation during cardiopulmonary bypass in the prevention of postoperative lung dysfunction. Perfusion 25:205-210.

131. Durukan AB, Gurbuz HA, Salman N, Unal EU, Ucar HI, Yorgancioglu CE (2013) Ventilation during cardiopulmonary bypass did not attenuate inflammatory response or affect postoperative outcomes. Cardiovasc J Afr 24:224-230.

132. Zupancich E, Paparella D, Turani F, Munch C, Rossi A, Massaccesi S, Ranieri VM (2005) Mechanical ventilation affects inflammatory mediators in patients undergoing cardiopulmonary bypass for cardiac surgery: a randomized clinical trial. J Thorac Cardiovasc Surg 130:378-383.

133. Reis Miranda D, Gommers D, Struijs A, Dekker R, Mekel J, Feelders R, Lachmann B, Bogers AJ (2005) Ventilation according to the open lung concept attenuates pulmonary inflammatory response in cardiac surgery. Eur J Cardiothorac Surg 28:889-895.

134. Beer L, Szerafin T, Mitterbauer A, Debreceni T, Maros T, Dworschak M, Roth GA, Ankersmit HJ (2013) Continued mechanical ventilation during coronary artery bypass graft operation attenuates the systemic immune response. Eur J Cardiothorac Surg 44:282-287.

135. Beer L, Szerafin T, Mitterbauer A, Debreceni T, Maros T, Dworschak M, Roth GA, Ankersmit HJ (2014) Low tidal volume ventilation during cardiopulmonary bypass reduces postoperative chemokine serum concentrations. Thorac Cardiovasc Surg 62:677-682

136. Ng CS, Arifi AA, Wan S, Ho AM, Wan IY, Wong EM, Yim AP (2008) Ventilation during cardiopulmonary bypass: impact on cytokine response and cardiopulmonary function. Ann Thorac Surg 85:154-162.

137. Chi D, Chen C, Shi Y, Wang W, Ma Y, Zhou R, Yu H, Liu B (2017) Ventilation during cardiopulmonary bypass for prevention of respiratory insufficiency: A meta-analysis of randomized controlled trials. Medicine (Baltimore) 96:e6454.

138. Schreiber JU, Lance MD, de Korte M, Artmann T, Aleksic I, Kranke P (2012) The effect of different lung-protective strategies in patients during cardiopulmonary bypass: a meta-analysis and semiquantitative review of randomized trials. J Cardiothorac Vasc Anesth 26:448-454.

139. Goldstein DJ, Moazami N, Seldomridge JA, Laio H, Ashton RC Jr, Naka Y, Pinsky DJ, Oz MC (1997) Circulatory resuscitation with left ventricular assist device support reduces interleukins 6 and 8 levels. Ann Thorac Surg 63:971-974.

\section{Submit your manuscript to a SpringerOpen ${ }^{\circ}$ journal and benefit from:}

- Convenient online submission

- Rigorous peer review

- Open access: articles freely available online

- High visibility within the field

- Retaining the copyright to your article

Submit your next manuscript at $\boldsymbol{\nabla}$ springeropen.com 